\title{
Adaptation of methodology of Discrete Fracture Network (DFN) model building for selected lower Paleozoic intervals
}

\begin{abstract}
Formation containing hydrocarbons, characterized as low permeable, has to be stimulated to begin fluid flow. Before stimulated process designing, model of discrete fracture network (DFN) has to be developed to predict pathways for hydrocarbon migration after stimulation process. Because shale formation has high content of TOC which is correlated with fracture presence, beside others, relation of these two parameters will be use to predict spatial distribution of natural fractures. Existence of this relation is a new, not considered so far in Polish fractured reservoirs, fracture driver. The purpose of article is an adaptation of DFN construction methodology for shale and sand formation from Baltic basin, Poland. In this case XRMI measurements and seismic data were used.
\end{abstract}

Key words: fracturing, DFN, modeling, fracture drivers, XRMI.

\section{Adaptacja metodyki konstrukcji modeli szczelinowatości dla wybranych poziomów dolnopaleozoicznych}

\begin{abstract}
Skały zasobne w węglowodory, charakteryzujące się anomalnie niskimi przepuszczalnościami, należy poddać zabiegom stymulacji, aby umożliwić przepływ mediów złożowych do odwiertów. Etapem poprzedzającym proces projektowania zabiegu szczelinowania analizowanego obiektu złożowego jest charakterystyka przestrzenna istniejącej już naturalnej szczelinowatości będącej odpowiedzią na panujący w otoczeniu reżim naprężeń, której sieć spękań stanowi potencjalną ścieżkę migracji płynów zakumulowanych w górotworze. W przypadku niekonwencjonalnych formacji typu shale, z uwagi na wspótistnienie zarazem skały macierzystej i zbiornikowej, mamy do czynienia z materią organiczną, której obecność - jak wykazano - istotnie wpływa na występowanie szczelin. Uwzględnienie istnienia zależności między TOC a parametrem intensywności zeszczelinowania stanowi nowy, nierozważany do tej pory w polskich warunkach, wskaźnik szczelinowatości dla budowy modelu sieci szczelin DFN (Discrete Fracture Network). Szczelinowatość analizowana była na wybranym obszarze Pomorza w wytypowanych interwałach: łupkowym i piaskowcowym dolnego paleozoiku, bazując na mikroopornościowych obrazach ścian otworów i danych sejsmicznych.
\end{abstract}

Słowa kluczowe: szczelinowatość, DFN, modelowanie, wskaźniki zeszczelinowania, XRMI.

\section{Introduction}

The presence of fractures in hydrocarbon reservoirs with low development of the porous space becomes crucial. The issue of DFN modelling is a multistage process combining many disciplines (structural geology, geophysics, deposit engineering, rock mass mechanics). In the light of availability of a broad spectrum of data, the modelling is a strategic function, due to the fact that the model contains all available data and indications for the analysed property of the deposit.
During the next stage, the developed DFN model undergoes parametrisation and then is used as input data in the simulation of flows in the porous-fractured deposit together with the rock matrix parameters. The occurrence of fracture network in the deposit formation significantly increases its attractiveness $[3,8]$ :

- natural fractures dictate the nature and direction of propagation for secondary fractures, 
- they connect in the stimulation process,

- they increase the drainage zone for the deposit formation,

- open fractures accumulate hydrocarbons.

The fracture nature of a medium is influenced by tectonic (related to the consequences of the stress regime applied to the medium) and non-tectonic factors (mineral composition, TOC, thickness of the formation) $[2,3,10]$. TOC is an important indication providing information about the propensity of shale formations to fracturing [7]. Shales with higher TOC are more brittle, with lower tensile strength and - as a consequence - are more susceptible to fracturing compared to similar rocks with lower TOC $[4,5]$. According to the classification based on the relation between TOC and shale rock susceptibility to fracturing [4], the Polish formations in the Baltic basin can be categorised as having limited susceptibility to fracturing.

\section{Interpretation of well log data}

Microresistivity images of rocks in three wellbores (separated by the distance of several kilometres) and seismic data were used to present the procedures leading to the spatial imaging of the fractures in the selected area in the form of a DFN model containing groups of planes with parameters reflecting the statistical aspect of the knowledge about interpreted fractures. The processing and interpretation of well $\log$ data was performed for the data from three wellbores in two intervals with a high resource potential, classified due to low permeability values as unconventional formations. The Techlog software was used for well log data interpretation and the DFN model was built in the Petrel software.

The stages of well log data interpretation included:

- integration and quality control of the high-resolution well $\log$ data from the microresistivity images of wellbore walls in the analysed wellbores;

- the processing of measured microresistivity images acquired with a Halliburton XRMI (X-tended Range Micro Imager) probe in order to obtain static and dynamic images in the analysed wellbores. The XRMI is a probe with six independent arms also used to measure the diameter of the wellbore - this enables accurate tracking of all washouts and breakouts on the wellbore walls. The probe enables electrical measurements with high vertical resolution of approx $5 \mathrm{~mm}$. Sonde provide $67 \%$ wellbore coverage in an $216 \mathrm{~mm}$ borehole. Lower wellbore diameters will result in higher coverage of the wallbore. The measurement data obtained in the process of acquisition are subject to required processing which takes into account: probe position in the wellbore (AZI1 - azimuth of pad 1 of the probe), probe orientation towards the north, borehole diameter, borehole deviation. Two microresitivity images: static and dynamic are the results of the processing. The static image is used to show the relative differences in resistance along the entire interval of the processed image, however it often does not show small important details, such as fractures, cracking, washouts. Appropriate filters are used to obtain a detailed, dynamic image of the wellbore wall - showing details often not visible on static images. The relative shift in colour values on dynamic images should not be applied to the entire measurement interval [7];

- interpretation of the natural fractures and cracking on XRMI images by the determination of the dipping angle of the fractures, their strike, dipping azimuth and type;

- identification and determination of the strike for drillinginduced fractures and breakouts based on XRMI images. They are important indicators of stress directions in the formation;

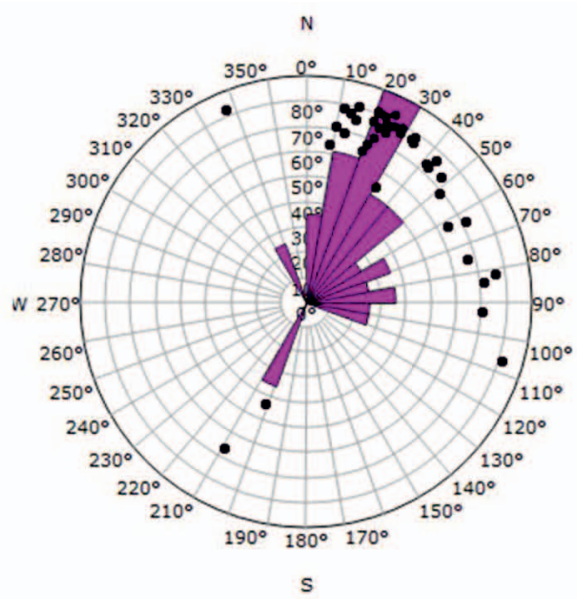

$\mathrm{S}$

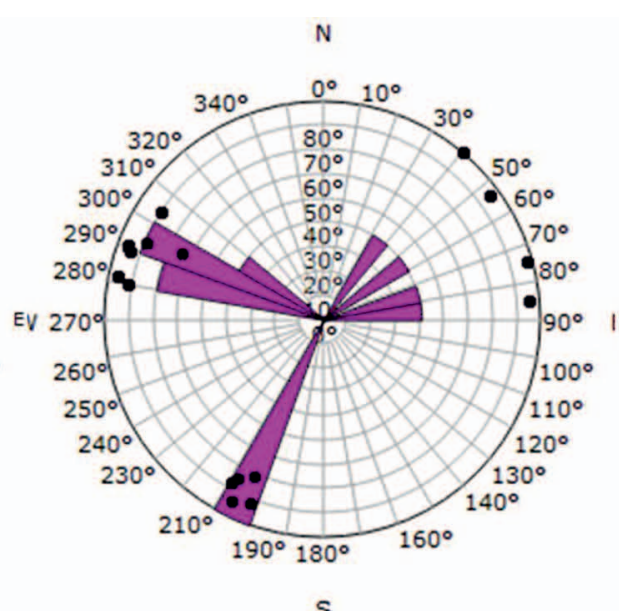

S

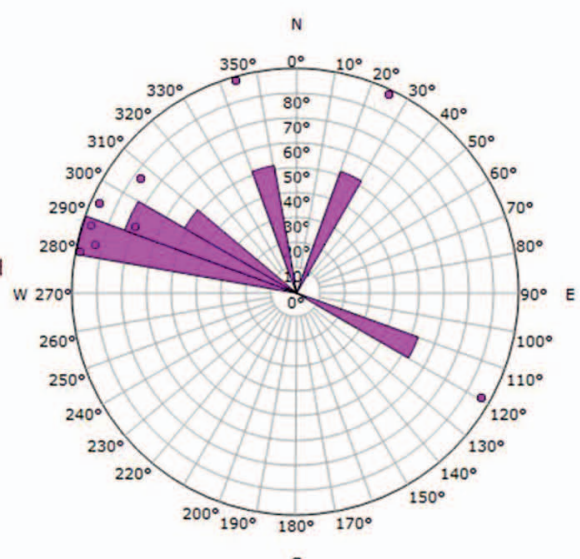

s

Fig. 1. Rose diagrams for the dipping azimuths of natural fractures for the interval including shale formations in the wellbores: O-1 (left), O-2 (centre) and O-3 (right) 
- collection of the interpretation results in the form of * $\operatorname{csv}$ and *las files with determined depth, dipping azimuth, dipping angle and type of fractures as well as using them as input data for the PETREL software used to create the DFN model.

The results of the interpretation of fractures on XRMI images are presented below in the form of rose diagrams showing the dominant dipping directions in shale formations (figure 1) and sandstone formations (figure 2) in the analysed wellbores.
Temperatures changes in the wellbore, due to the drilling fluid circulation, are conducive to the occurrence of such fractures. The strike of tensile fractures enables the determination of the maximum stress direction - for the analysed area: approx. 110-140 degrees SE.

In sandstones, the determination of the dominant fracture dipping direction is often difficult (figure 3). The XRMI image for this interval is often of poor quality, particularly in the O-3 wellbore. Probably, the content of hydrocarbons affects the quality of measurement data - their presence masks the

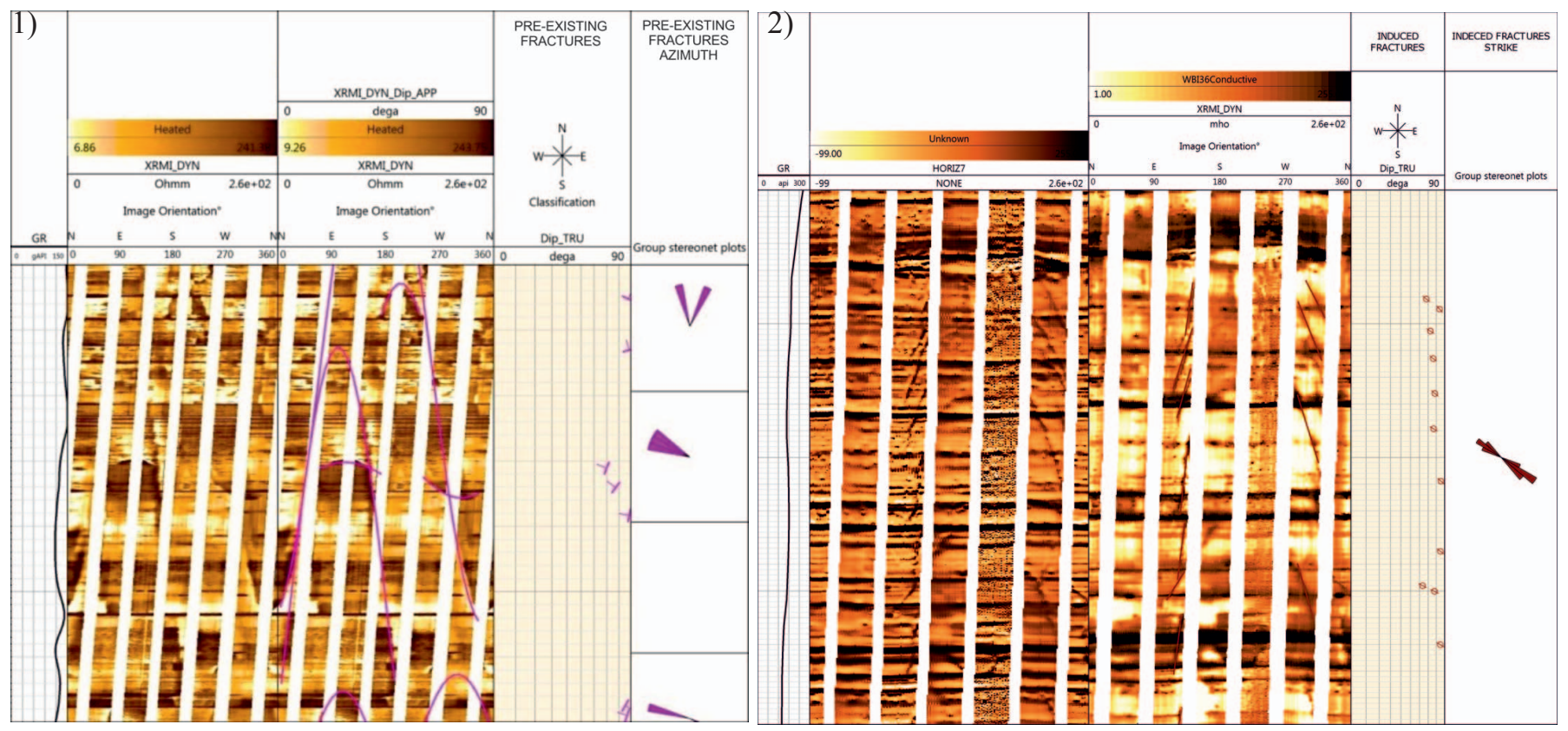

Fig. 2. Example of occurring natural fractures with high dipping angles visible in within the shale formation in the O-3 wellbore (1); strike of induced fractures in the O-2 wellbore (2)

In the shale formation in the $\mathrm{O}-1$ wellbore, we can observe one dominant dipping direction for natural fractures - NNE (10-30 degrees). In the shale formation in wellbore O-2, there are visible occurrences of 3 groups of fractures dipping towards the NE, SSW (200 degrees) and NWW (280-300 degrees). In the O-3 wellbore, the dominant natural fracture dipping direction is NWW (280-290 degrees).

In the shale formations of the O-1 and O-2 wellbores, we can also observe, in addition to the natural fractures, induced fractures with the NW-SE course. Drilling induced fractures are a type of fractures which, in vertical wellbores, develop in the direction of the maximum stress in the wellbore, i.e. perpendicular to the breakouts. They are mostly fractures positioned vertically or almost vertically along the wellbore. changes in resistance of the near-wellbore zone. O-1 and O-2 wellbores present better quality data for this interval. Based on the fractures interpreted in the O-2 wellbore, 3 dominant dipping azimuths can be observed: $\mathrm{NE}-80$ degrees, $\mathrm{SW}-210$ degrees and NW 260-290 degrees. In wellbore O-2, we

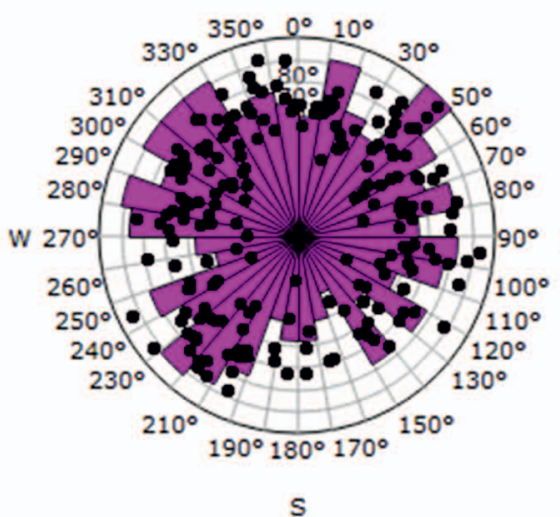

S

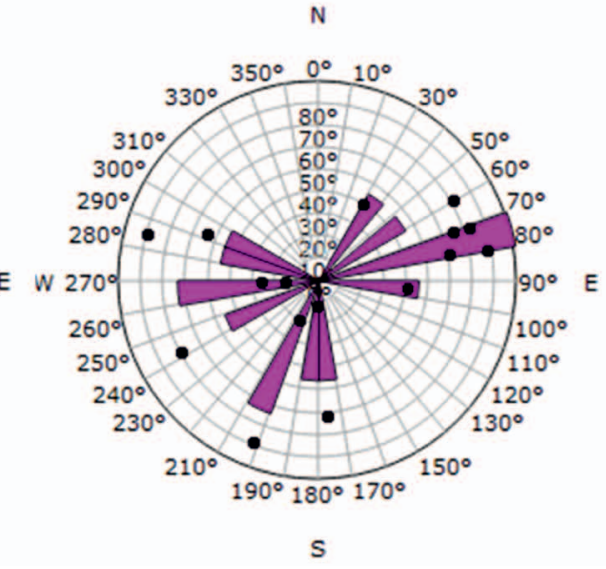

Fig. 3. Rose diagram for the dipping azimuth of natural fractures for the interval including sandstone formations in the wellbores: O-1 (left) and O-2 (right) 
can also observe induced fractures with strike similar to the course of induced fractures in shale formations as well as breakout structures with the strike (NE-SW) determined by the minimum stress direction.

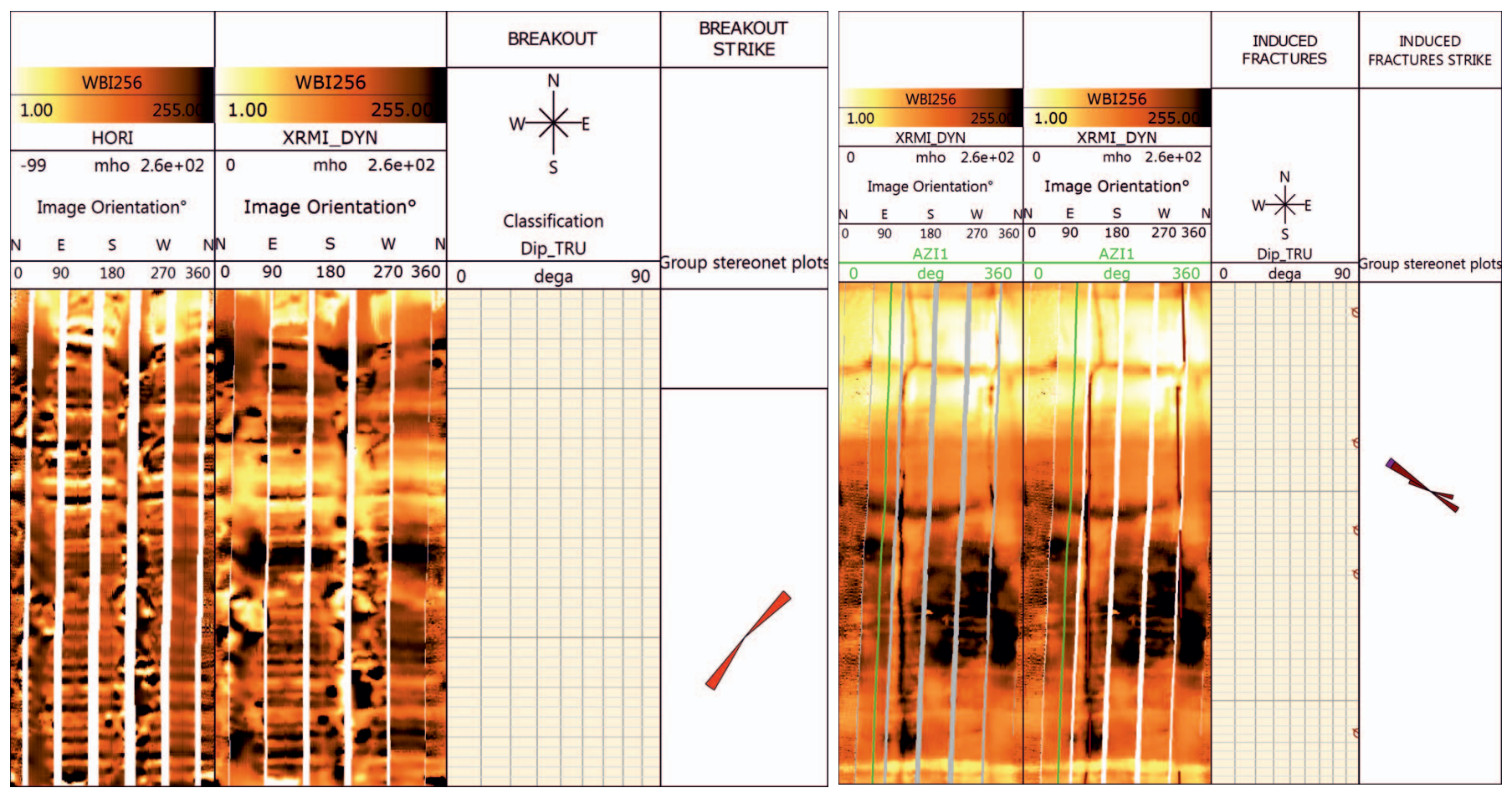

Fig. 4. Breakout-type structures (on the left) and drilling-induced fractures (on the right) visible on XRMI images within the sandstone interval in the O-2 wellbore

\section{DFN modelling}

Well data (locations of wellbores, stratigraphy, interpretation of fractures and well logs) and seismic data (structural interpretations, seismic inversion results, seismic attributes) are primarily collected in the process of recreating the spatial distribution of fractures intensity - they will be the first to be used in the construction of a structural model used to analyse the available data, for example for the definition of fracture sets, statistical description of the significant parameters of fractures and calculation of the fracture intensity curves. In the next stage, the wellbore and seismic data are integrated in the set grid resolution (selected to match the level of data detail) in order to increase the reliability of recreating the spatial variability of the fracturing intensity parameter. The final stage involves the definition of parameters, such as: geometry and orientation of fractures - separately for each of the defined fracture sets as well as the method of distribution of fractures controlled by the spatial distribution of the fracture intensity parameter, determining the number of fractures in each calculation block of the interpolation grid or a constant value. Workflow of the procedures related to the construction of the DFN model is presented below (figure 5).

Two intervals of lower Paleozoic in the area of Polish Baltic basin were modelled: shale (with average thickness of $23 \mathrm{~m}$ ) and sandstone (average thickness of $84 \mathrm{~m}$ ). In addition, in order to provide more details for the DFN model, zones with the radius of $500 \mathrm{~m}$ were created near the available wellbores - in these zones, values for specifically selected fracture sets will be provided on the model definition stage.

The results of fracture interpretations on XRMI profiles (depths, dip angle, dip azimuth for individual fractures and assigned types related to their genesis) were imported into the project and analysed as local point data. These data have two purposes: they enable the calculation of the fracturing intensity parameter as a value variation curve for this parameter in the wellbore profile and the division of all observed fractures into groups with varying orientations in order to provide a more accurate representation of the nature of the fracture network within the spatial DFN model. For this purpose, a visualisation of the fracture orientation in the form of points on stereographic projections was used - the division criteria were the dip angle and dip azimuth values for each of the identified fractures. The analysis should be based on the observations of fractures in specified intervals, e.g. lithostratigraphic or facial separations. This will enable the distinction of fracture sets related to specific rock formations, characterised by, e.g. variable susceptibility to fracturing. 


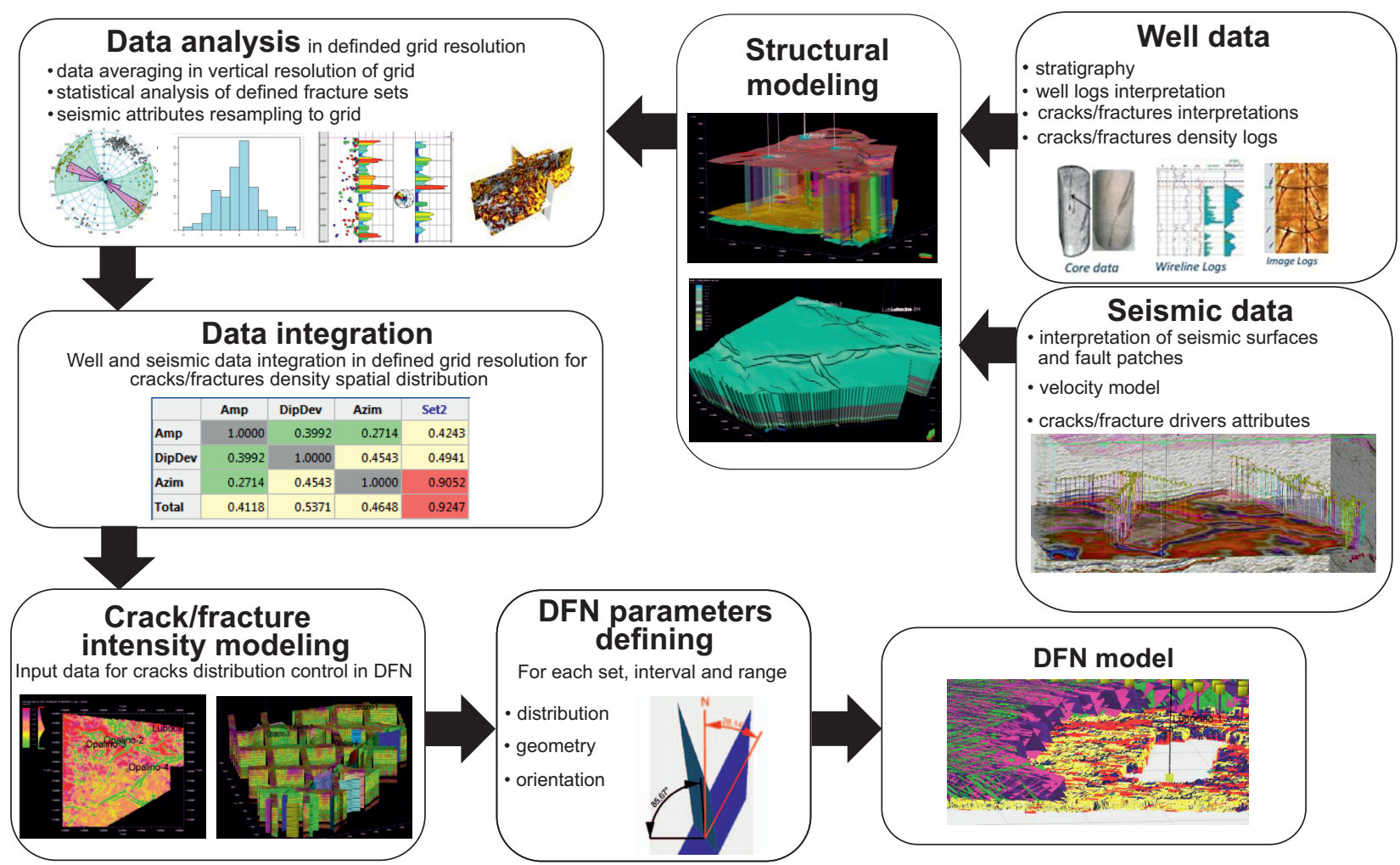

Fig. 5. Workflow applied to build a Discrete Fracture Network model
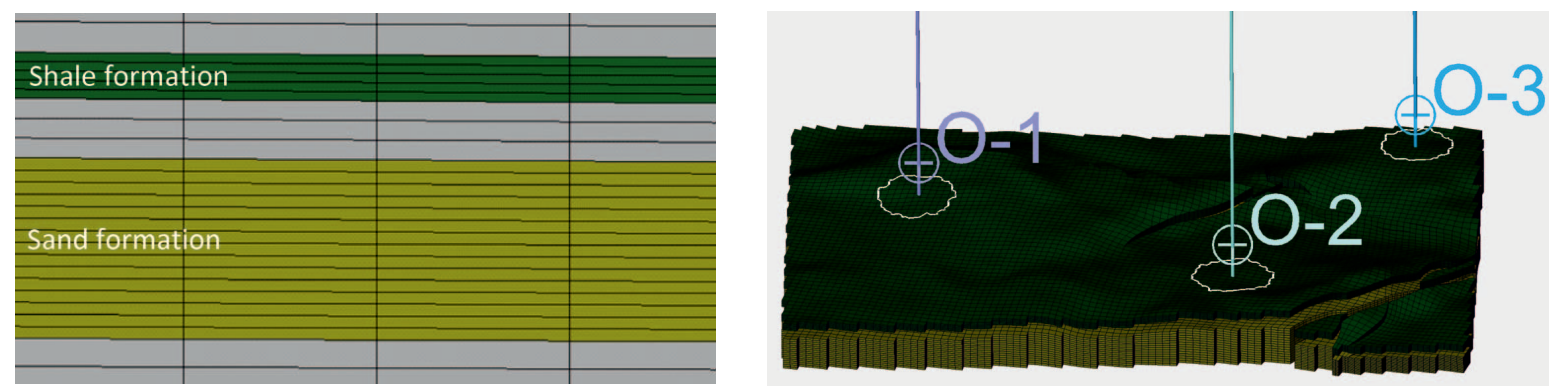

Fig. 6. Structural model within the analysed area. The white polygon around the borehole marks the range of the detailed near-wellbore models

As part of this study, the first step was to limit the visualisation of points from the entire profile of wellbores to defined intervals. In the case of fractures found in the shale interval - they are grouped due to the dip azimuth, as evidenced by the rose diagram dictating three major directions $\left(15^{\circ}\right.$, $\left.135^{\circ}, 300^{\circ}\right)$. Furthermore, fracture sets in the near-wellbore zones were determined separately for each of the wellbores (figure 7a). 12 sets in total were distinguished for the shale interval: Set1a and b, Set $2 a$ and b (4 sets for the sum of observations from all wellbores - figure 7b), O-1a, b and c, O-2a, b, c, O-3a and b (8 sets defined separately for each of the wellbores - figure 7a). The analysis of the fractures observations presented on the stereographic projection in the sandstone interval (figures $7 \mathrm{c}$ and $7 \mathrm{~d}$ ) shows significant variability of the dip angle and dip azimuth values which prevented the definition of distinctive sets of fractures.
In the next stage, fracture intensity (observations count) curves were generated for each of the identified sets of fractures. Due to the limited number of wellbore data, in order to improve the reliability of the recreation of the fracturing intensity parameter spatial variability, the so-called fracture drivers are used. In the literature, the following drivers carrying information about the potential presence of fractures are distinguished [6]:

- structural-tectonic, related to the presence of faults and curvatures of structural surfaces,

- geomechanical, related to the existing rock mass stresses,

- seismic - seismic attributes, AVAZ analyses,

- others, e.g. lithological composition, formation thickness. Regarding indications of a relationship between the TOC and the occurrence of fractures, the fracturing intensity curves calculated for the dominant fracture sets were 

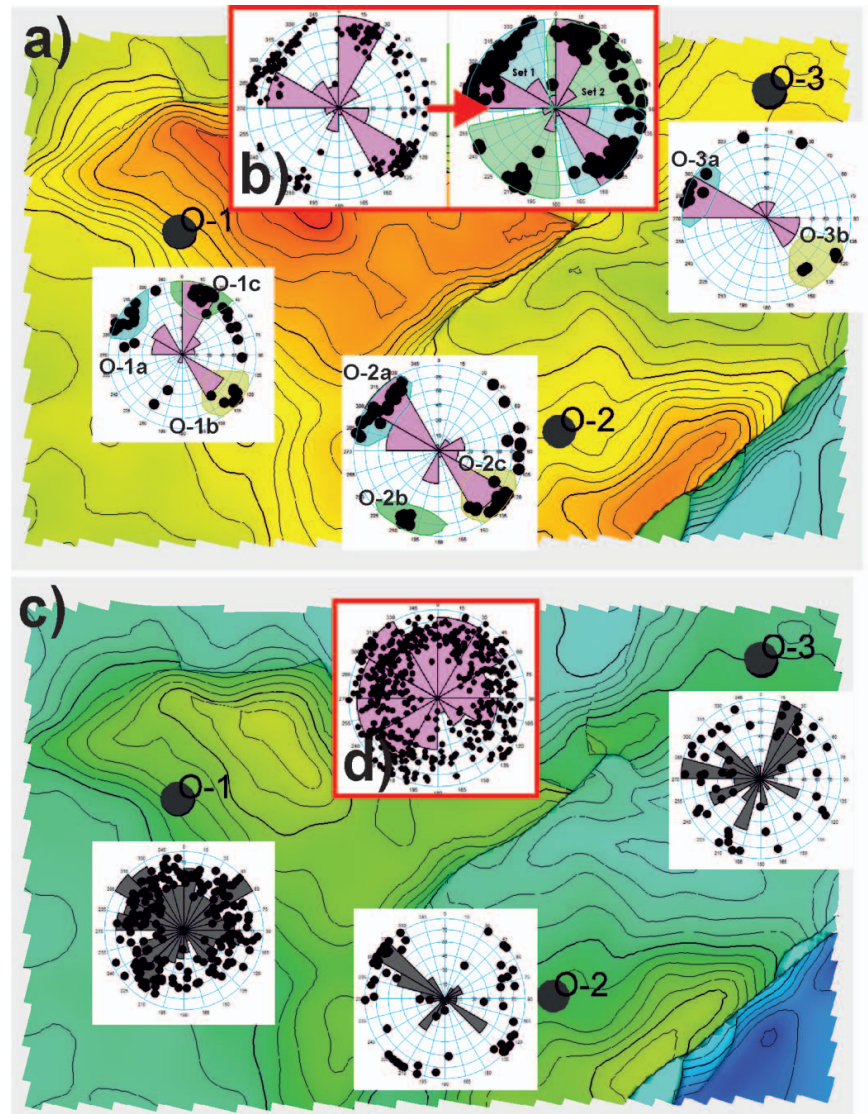

Fig. 7. Orientations of fractures in the shale (top) and sand (bottom) intervals with distinguished sets (a) for each of the wellbores, (b) orientation of the sum of fractures with defined sets (c) separately for each wellbore, (d) stereographic projection of all identified fractures. In the background structural top surfaces of appropriate intervals

compared to the organic matter content curves to show the mutual relationship at the level of 0.44 correlation factor (figure 8a), particularly distinct for the analysis of the fracturing intensity curves for dominant fracture sets (correlation factor of 0.77 ) (figure 8b). Out of all the analysed fracturing indicators, this parameter is the most strongly related to fracturing intensity.

The fracturing intensity models controlling the density of fractures in each of the calculation blocks of the DFN a)

b)
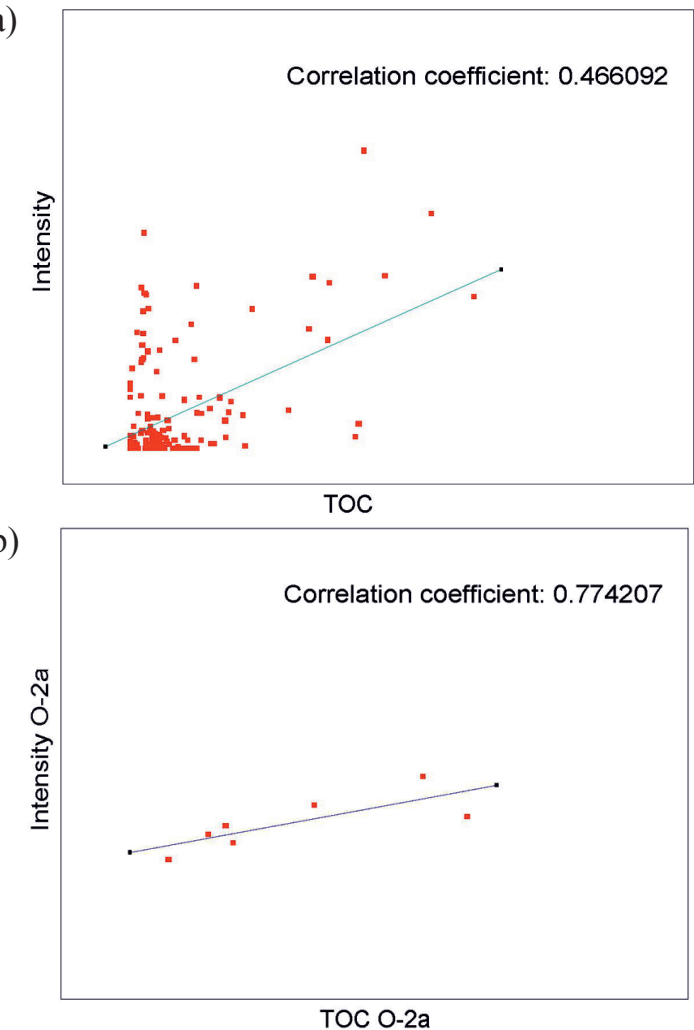

Fig. 8. Relationship between the organic matter content and fractures intensity in shale formations: a) for all wellbores, b) for one dominant fracture set in the selected wellbore

model [9] were calculated using the strong correlation between the set fracturing intensity and fracture drivers available in the spatial version of the data. The fracturing intensity models with maps of average values for this parameter are presented below (figures 9 and 10).

The calculated spatial distributions of fracture intensity for the distinguished groups of fractures are a parameters defining the density of fractures in the DFN model. Other required values are the geometric parameters of fractures within a group, their assumed shape, data defining the orientation of fractures, i.e. average dip angle and azimuth as well as the concentration factor determining the distribution of the orientations in the modelled network of fractures with
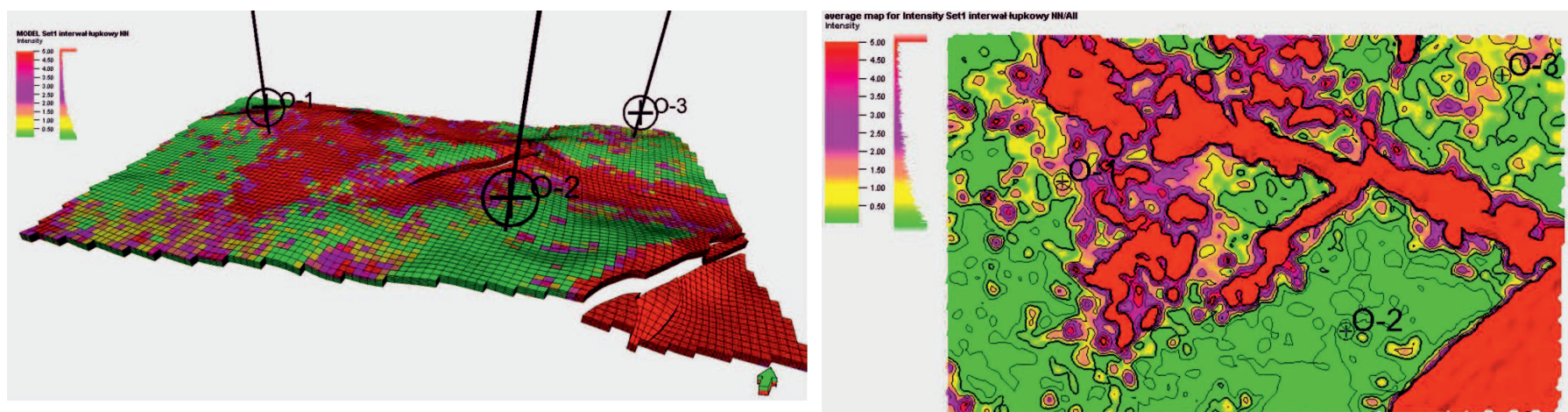

Fig. 9. Results of modelling the fracturing intensity parameter for the shale interval (left) and map of average values (right) 

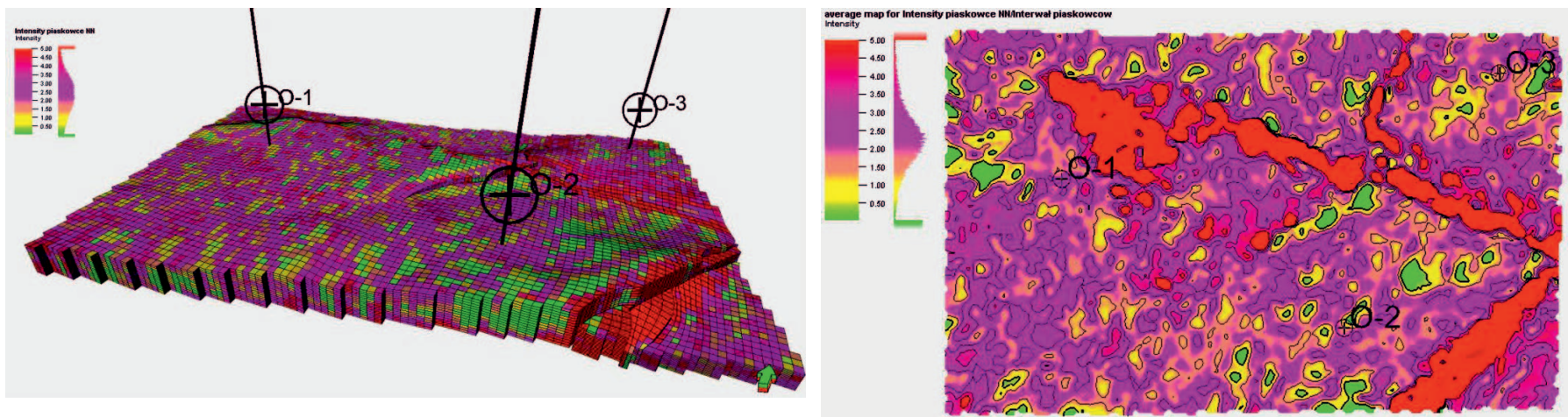

Fig. 10. Results of modelling the fracturing intensity parameter for the sandstone interval (left) and map of average values for this parameter (right)

assumed average values. The result is a DFN model depicting the distribution of the network of fractures within individual groups in the form of planes located within the defined area (figures 11, 12, 13).

The awareness of limited knowledge about the analyzed reservoir area and the amount of data available with different degrees of reliability, as well as a number of simplified methodological assumptions made in the construction of parametric models, obliges to carry out a quantitative analysis of the uncertainty of the obtained results. Assessing the uncertainty of the obtained results should be final stage of parametric modelling process.

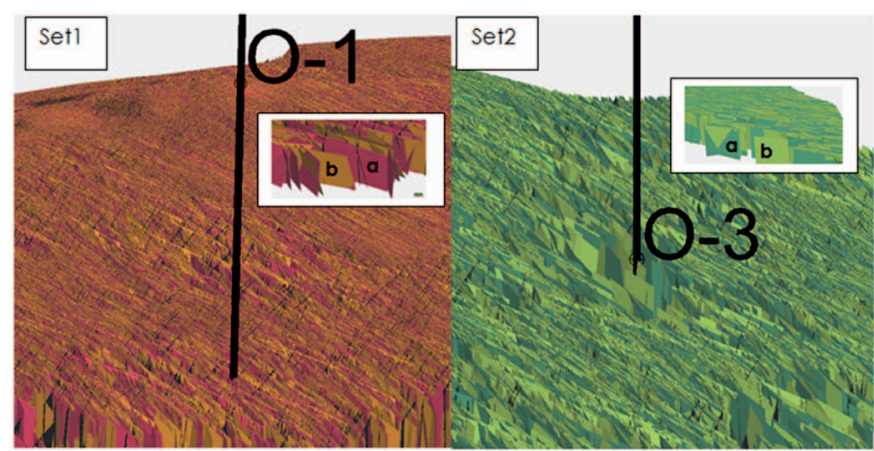

Fig. 11. DFN model for the defined fracture sets (Setla, Set1b - view around the O-1 wellbore; Set2a and Set2b - view around the O-3 wellbore) for the zone between and outside the wellbores in the shale interval
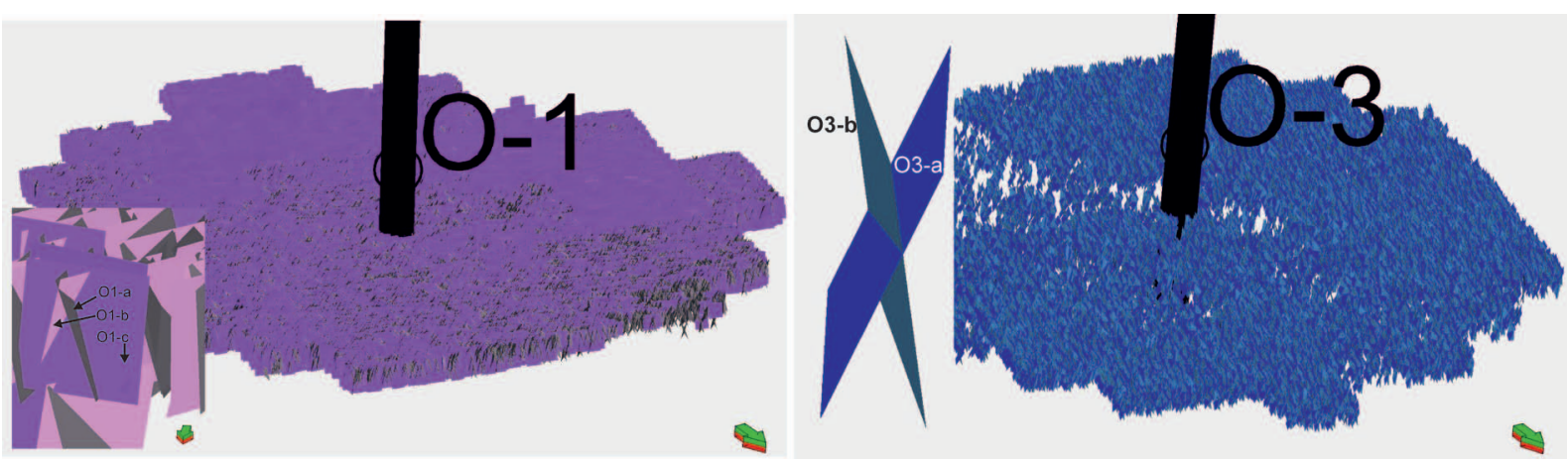

Fig. 12. DFN model for near-wellbore zones, representing fracture sets defined (fig. 7) individually for each of the wellbores (wellbore O-1 - sets: O-1a, b, c; wellbore O-3 - sets: O-3a, b) in the shale formation interval

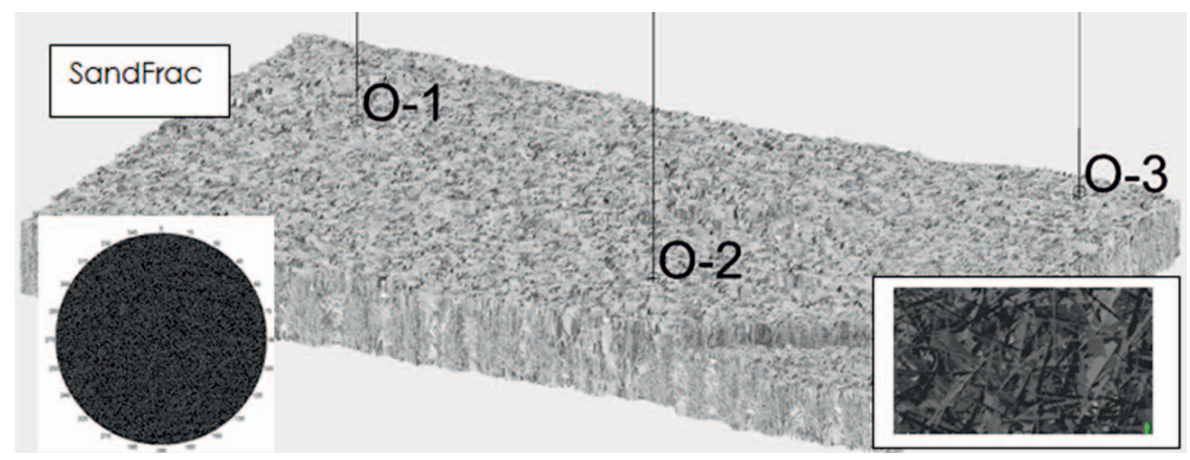

Fig. 13. Model of the natural fractures network in the sandstone interval 


\section{Conclusion}

The direct factors related to the occurrence of fractures in the analysed area are: tectonic activity and the presence of organic content which was transformed due to high pressure and temperature. The analysis of the fracture network in two different formations presented in the article shows the different nature of fractures. The fractures identified in the shale formation are clearly distinct and grouped into sets, they also display high dip angles. In shale formation fractures are mainly located in the near-fault zone. The fractures in the sandstone interval, on the other hand, dip along the entire range of dip angle and azimuth. The results of DFN modelling, in the local aspect (near-wellbore zone) as well as the areas between and outside wellbores together with the geomechanical model representing the stress patterns in the rock mass provide support for the tasks of optimisa- tion of wellbore design, determination of optimal zones for the stimulation and forecasting of the effects of fracturing operations. The fracture network model constructed with the highest available degree of precision is then subject to parametrisation in order to simulate the deposit fluid flows through the medium. For this purpose, a dual porosity and permeability is prepared based on laboratory data, interpretation of drilling geophysics curves and seismic data and then calibrated with hydrodynamic tests. This set of static models (petrophysical parameters - including the DFN fracture model and geomechanical model), integrating all available information, subjected to simulations, with the resource evaluation and uncertainty analysis - provide a cohesive image of the potential of the reservoir, sufficient to conclude over the economic efficacy of extraction.

Please cite as: Nafta-Gaz, no. 11, 2017, pp. 843-850, DOI: 10.18668/NG.2017.11.03

Article contributed to the Editor 23.12.2016. Approved for publication 11.07.2017.

The article is based on the statutory study entitled: Metodyka konstrukcji przestrzennych modeli szczelinowatości wybranych poziomów dolnopaleozoicznych (Methodology of Discrete Fracture Network (DFN) model building for selected lower Paleozoic intervals) - paper by the Oil and Gas Institute - National Research Institute by order of the Ministry of Science and Higher Education; order no.: 0014/SG/16/01, archive no.: DK-4100-/14/16.

\section{Literature}

[1] Bartoń R., Wilk A.: Wyznaczanie rozkładu szczelin w formacjach typu shale gas na podstawie azymutalnych pomiarów sejsmicznych. Nafta-Gaz 2016, no. 12, pp. 1011-1017, DOI: 10.18668/NG.2016.12.01.

[2] Chopra S., Sharama R.K., Keay J., Marfurt K.J.: Shale gas reservoir characterization workflows. SEG Las Vegas 2012, Annual Meeting 2012, pp. 1-5.

[3] Dershowitz W., Doe T.: Modeling Complexities of Natural Fracturing Key in Gas Shales. American Oil \& Gas Reporter 2011, pp. 1-4.

[4] Ding W., Li Chao, Li Ch., Xu Ch., Jiu K., Zeng W., Wu L.: Fracture development in shale and its relationship to gas accumulation. Geoscience Frontiers 2011, vol. 3, no. 1, pp. 97-105.

[5] MacKay M., Eaton D., Clarkson C.: Predicting the microseismic response in a naturally fractured shale reservoir using a discrete frature network model. GeoConvention 2016, Calgary, Canada 7-11.03.2016, pp. 1-4.

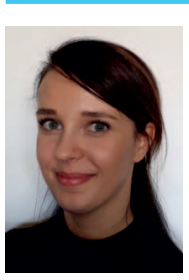

Mgr inż. Weronika KACZMARCZYK

Asystent w Zakładzie Geologii i Geochemii. Instytut Nafty i Gazu - Państwowy Instytut Badawczy ul. Lubicz 25 A

31-503 Kraków

E-mail: weronika.kaczmarczyk@inig.pl

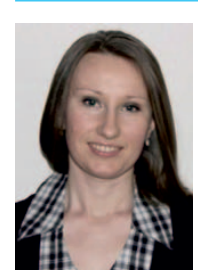

Mgr inż. Anita LIS-ŚLEDZIONA

Asystent w Zakładzie Geologii i Geochemii. Instytut Nafty i Gazu - Państwowy Instytut Badawczy ul. Lubicz 25 A

31-503 Kraków

E-mail: anita.lis@inig.pl 